See discussions, stats, and author profiles for this publication at:

https://www.researchgate.net/publication/11980102

\title{
Synovial sarcoma and malignant mesothelioma of the pleura: Review, differential diagnosis and possible role of apoptosis
}

Article in Pathology · June 2001

DOI: 10.1080/00313020120038728 · Source: PubMed

2 authors:

\section{Francesco Cappello}

University of Palermo, Palermo, Italy

279 PUBLICATIONS 3,378 CITATIONS

SEE PROFILE

\section{Leon Barnes}

University of Pittsburgh

251 PUBLICATIONS 9,425 CITATIONS

SEE PROFILE 


\title{
SYNOVIAL SARCOMA AND MALIGNANT MESOTHELIOMA OF THE PLEURA: REVIEW, DIFFERENTIAL DIAGNOSIS AND POSSIBLE ROLE OF APOPTOSIS
}

\author{
Francesco Cappello* and Leon Barnes $\dagger$ \\ Institute of Pathological Anatomy, University of Palermo, Palermo, Italy*; and the Department of \\ Pathology, University of Pittsburgh Medical Center, Presbyterian Hospital, Pittsburgh, Pennsylvania, USA $\dagger$
}

\section{Summary}

Synovial sarcoma of the pleural cavity is exceptionally rare and may be confused, both clinically and histologically, with malignant mesothelioma, with subsequent inappropriate therapy. To address this dilemma, four biphasic synovial sarcomas (BSSs) and four biphasic malignant mesotheliomas (BMMs) were studied with a panel of mucin and immunohistochemical stains to determine if they would allow one to distinguish between the two. The BMMs were all pleural-based. The BSSs were extrapleural. The mucin and immunohistochemical stains were all performed on formalinfixed, paraffin-embedded tissue using standard techniques, with appropriate positive and negative controls. Mucin present in BSS is, in general, mucicarmine-positive and resistant to both hyaluronidase and diastase. Of the immune markers evaluated, only calretinin, Ber-Ep4 and bcl-2 were of limited discriminatory value. Subsets of cytokeratins, CEA and $C D 34$ were not helpful. With the exception of bcl-2, the apoptotic markers p53, bax and cpp32 (caspase) also were not useful. However, when the apoptotic stains were viewed collectively, variations in expression between the two tumours raised the possibility that alterations in apoptotic activity might be responsible for their pathogenesis and behavior. The diagnosis of BSS or BMM of the pleural should be made only after total consideration of clinical, radiological, histochemical and immunohistochemical findings. Although mucin stains are useful in differential diagnosis, reliance solely on immunohistochemical markers, with the possible exception of calretinin, Ber-Ep4 and bcl-2, is not dependable. The role of apoptosis in the pathogenesis of these tumours needs to be explored with a much larger series.

Key words: Synovial sarcoma, malignant mesothelioma, immunohistochemistry, apoptosis.

Received 7 July 2000; revised 6 December; accepted 14 December

\section{INTRODUCTION}

Synovial sarcomas comprise 5-10\% of all soft tissue tumours and occur primarily in adolescents and young adults between 15 and 40 years of age. ${ }^{1-3}$ Most arise in the extremities in the vicinity of large joints. While the name implies an origin from synovium, they rarely involve or arise from preformed synovium. Instead, they are thought to originate from primitive pluripotential mesenchyme capable of synovial differentiation. This explains their origin in unusual sites devoid of normal synovium, such as the base of the tongue, abdominal wall and pleural cavity. ${ }^{4-9}$ In the latter location, the diagnosis is often not considered and, because of its histological similarity, may be mistaken for a malignant mesothelioma, with subsequent inappropriate therapy.

To address this diagnostic dilemma, we studied four pleural-based, biphasic malignant mesotheliomas (BMMs) and four extrapleural, biphasic synovial sarcomas (BSSs) using a variety of mucin stains and a panel of immunohistochemical markers (Table 1) to see if they would allow one to distinguish between these two neoplasms. The results of some of the immune markers suggest, rather expectedly, that variances in apoptosis may be a factor in the pathogenesis of these neoplasms.

\section{MATERIALS AND METHODS}

The anatomic pathology files of the Department of Pathology of the University of Pittsburgh Medical Center, Presbyterian Hospital, were searched for cases of biphasic synovial sarcoma and biphasic malignant mesothelioma that were confirmed by light microscopy, supplemented with histochemical, immunohistochemical and ultrastructural procedures.

Four cases of each tumour that were formalin-fixed and paraffinembedded were selected. The mesotheliomas were all pleural-based. In order to avoid any confusion with a mesothelioma, only extrapleural synovial sarcomas were studied.

All cases were evaluated with three mucin stains: mucicarmine, alcian blue with and without hyaluronidase, and periodic acid-Schiff with and without diastase. The mucin content was scored as either absent $(-)$ or present $(+)$.

TABLE 1 Immunohistochemical reagents used in this study

\begin{tabular}{lclc}
\hline Antibody & Type & Dilution & Source \\
\hline Cytokeratin 5/6 & Monoclonal & $1: 25$ & Boehringer Mannheim \\
Cytokeratin 7 & Monoclonal & $1: 100$ & DAKO \\
Cytokeratin 8 & Monoclonal & $1: 100$ & Sigma \\
Cytokeratin 18 & Monoclonal & $1: 500$ & Sigma \\
Cytokeratin 19 & Monoclonal & $1: 50$ & DAKO \\
CEA & Monoclonal & $1: 50$ & DAKO \\
Calretinin & Polyclonal & $1: 20$ & Zymed \\
CD 34 & Monoclonal & $1: 40$ & DAKO \\
Ber-Ep4 & Monoclonal & $1: 20$ & DAKO \\
p53 & Monoclonal & $1: 100$ & Biogenex \\
Bcl-2 & Polyclonal & $1: 10$ & DAKO \\
Bax & Monoclonal & $1: 30$ & Biogenex \\
Caspase 3 & Polyclonal & $1: 500$ & Pharmingen \\
& & & \\
\hline
\end{tabular}




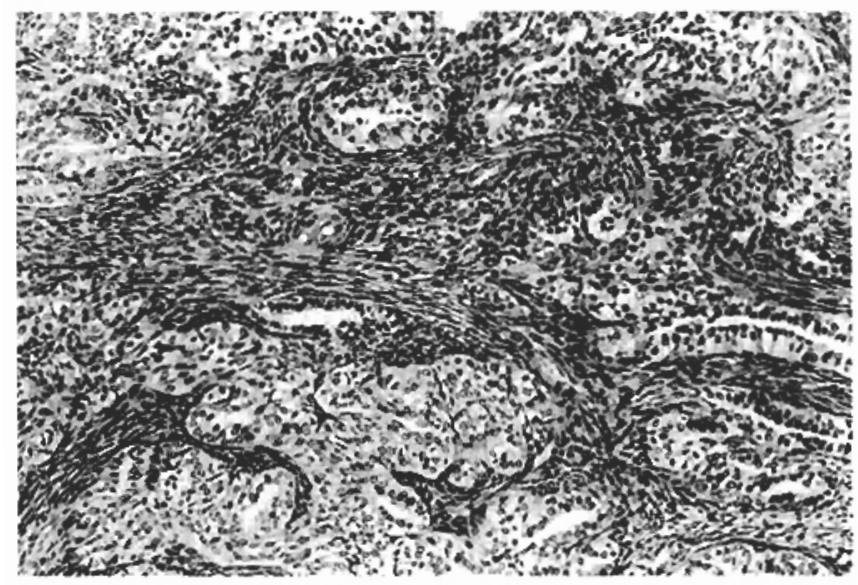

Fig. 1 Synovial sarcoma, biphasic type. The epithelial component appears as solid clusters and as glands. The spindle cell element is compact. Compare with the biphasic malignant mesothelioma shown in Fig. 2 (H\&E, original magnification, $\times 100)$.

Immunohistochemical staining was performed using the standard avidin-biotin peroxidase technique. The antibodies employed and their characteristics are shown in Table 1. Non-immune mouse and rabbit sera were substituted for negative controls. Appropriate positive controls were run concurrently for all antibodies tested. The stains were semiquantitated on a scale of $0-3+$ (absent to strongly positive: $1<25 \%$ of the cells, $3>75 \%$ of the cells).

\section{RESULTS}

\section{Clinicopathological features}

The clinical and pathological characteristics of the tumours in this study are listed in Table 2. All were of the classic, biphasic type which have been described in detail by others ${ }^{1,3,10,11}$ (Figs. 1 and 2). The ratio of epithelial to spindle cells was highly variable, with the epithelial component comprising $20-60 \%$ of the total volume of the tumours that were sampled for microscopic evaluation.

\section{Mucin stains}

The results of the mucin stains are summarised in Table 3. With the mucicarmine stain, mucin was focally detected in the epithelial component (lumens of glands and/or cytoplasm of epithelial cells) in three out of four BSSs and none of the BMMs.

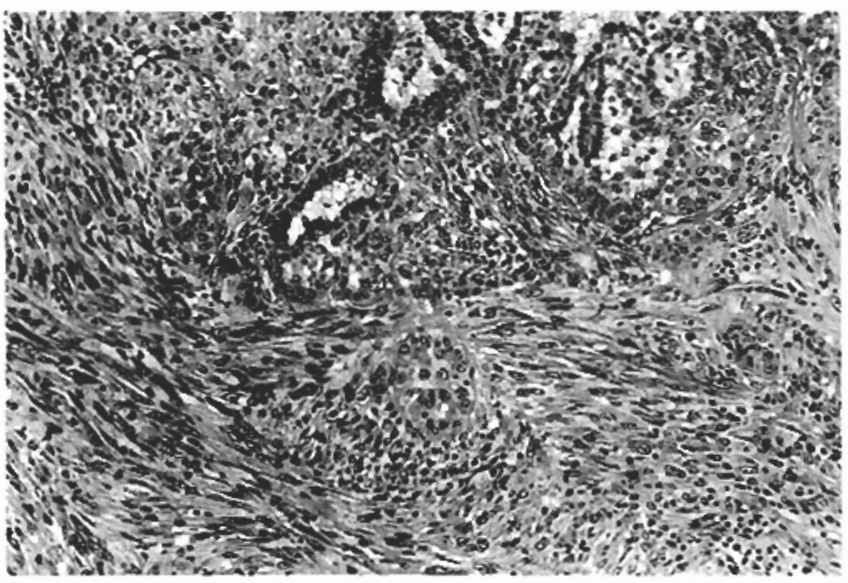

Fig. 2 Malignant mesothelioma, biphasic. Although histologically similar, the spindle component in malignant mesothelioma tends to be less "compact" than that seen in synovial sarcoma (H\&E, original magnification, $\times 100$ ).

Alcian blue without prior hyaluronidase digestion was weakly positive in the epithelial and spindle cells in three of four BSSs and only in the spindle cell component in one of four BMMs. With hyaluronidase digestion, the alcian blue positivity persisted in the BSSs and was abolished in the BMM.

The periodic acid-Schiff (PAS) stain showed focal positive staining in the epithelial component in four of four BSSs and in three of four BMMs. With diastase digestion, the PAS-positivity persisted in all BSSs and was negative in all three BMMs that had been previously positive.

\section{Immunohistochemical stains}

The results of the immunohistochemical procedures are given in Table 4. In general, stains for the various cytokeratins (numbers $5 / 6,7,8,18,19$ ) were moderately to strongly positive in the epithelial component of all tumours, while the spindle cells were either negative or weakly to moderately positive. CEA and CD 34 were uniformly negative in all tumours.

Although calretinin was focally weakly positive in four of four BSSs, the positivity was limited to the spindle cells in 3 (Fig. 3). Only one tumour exhibited staining of both epithelial and spindle cells. In contrast, the epithelial cells in four of four BMMs were strongly positive, while the spindle cells were uniformly negative (Fig. 4).

TABLE 2 Clinicopathological features of tumours in this study

\begin{tabular}{lcclc}
\hline & Age & Sex & Site & Tumour size (cm) \\
\hline Biphasic synovial sarcoma & & & & 5 \\
Case 1 & 18 & M & Left cervical esophagus & 5.3 \\
Case 2 & 29 & M & Right retropharynx & 4 \\
Case 3 & 19 & M & Right cervical esophagus & 7 \\
Case 4 & 67 & F & Right forearm & \\
Biphasic malignant mesothelioma & & & & Diffuse \\
Case 1 & 81 & M & Diaphragmatic pleura & Diffuse \\
Case 2 & 72 & M & Right pleura & Diffuse \\
Case 3 & 62 & M & Right pleura & Diffuse \\
Case 4 & 67 & F & Left pleura & .
\end{tabular}


TABLE 3 Results of mucin stains on tumours in this study

\begin{tabular}{|c|c|c|c|c|c|}
\hline Case & Mucicarmine & $\begin{array}{c}\text { Alcian blue } \\
\text { without } \\
\text { hyaluronidase }\end{array}$ & $\begin{array}{l}\text { Alcian blue } \\
\text { with } \\
\text { hyaluronidase }\end{array}$ & $\begin{array}{c}\text { PAS } \\
\text { without } \\
\text { diastase }\end{array}$ & $\begin{array}{c}\text { PAS with } \\
\text { diastase }\end{array}$ \\
\hline BSS 1 & + & - & - & + & + \\
\hline BSS 2 & - & + & + & + & + \\
\hline BSS 3 & + & + & + & + & + \\
\hline BSS 4 & + & + & + & + & + \\
\hline BMM 1 & - & + & - & - & - \\
\hline BMM 2 & - & - & - & + & - \\
\hline BMM 3 & - & + & - & + & - \\
\hline BMM 4 & - & + & - & + & - \\
\hline
\end{tabular}

TABLE 4 Results of immunohistochemical stains on tumours in this study

\begin{tabular}{|c|c|c|c|c|c|c|c|c|c|c|c|c|c|c|}
\hline Case & Growth pattern & CK 5/6 & CK 7 & CK 8 & CK 18 & CK 19 & CEA & Calretinin & Ber-Ep4 & CD 34 & p53 & bcl-2 & bax & cpp32 \\
\hline \multirow[t]{2}{*}{ BSS 1} & Epithelial & ++ & +++ & ++ & +++ & +++ & - & - & + & - & +++ & - & ++ & ++ \\
\hline & Spindle & - & - & - & + & - & - & + & - & - & - & +++ & - & - \\
\hline \multirow[t]{2}{*}{ BSS 2} & Epithelial & +++ & +++ & +++ & +++ & +++ & - & - & - & - & ++ & - & + & + \\
\hline & Spindle & + & - & - & - & - & - & + & - & - & - & +++ & + & - \\
\hline \multirow[t]{2}{*}{ BSS 3} & Epithelial & +++ & +++ & ++ & +++ & +++ & - & - & ++ & - & ++ & + & ++ & ++ \\
\hline & Spindle & + & - & - & - & - & - & + & - & - & + & +++ & + & + \\
\hline \multirow[t]{2}{*}{ BSS 4} & Epithelial & + & + & - & + & + & - & + & - & - & - & ++ & + & + \\
\hline & Spindle & ++ & ++ & - & ++ & - & - & ++ & - & - & + & +++ & + & + \\
\hline \multirow[t]{2}{*}{ BMM 1} & Epithelial & +++ & +++ & +++ & +++ & +++ & - & ++ & - & - & + & + & + & ++ \\
\hline & Spindle & + & + & - & - & - & - & - & - & - & + & + & ++ & + \\
\hline \multirow[t]{2}{*}{ BMM 2} & Epithelial & ++ & - & + & ++ & ++ & - & +++ & - & - & + & + & ++ & + \\
\hline & Spindle & + & - & + & + & + & - & - & - & - & + & ++ & ++ & + \\
\hline \multirow[t]{2}{*}{ BMM 3} & Epithelial & +++ & +++ & +++ & +++ & +++ & - & +++ & - & - & + & + & ++ & ++ \\
\hline & Spindle & + & - & + & + & - & - & - & - & - & + & ++ & +++ & + \\
\hline \multirow[t]{2}{*}{ BMM 4} & Epithelial & +++ & +++ & +++ & +++ & +++ & - & +++ & - & - & + & + & ++ & + \\
\hline & Spindle & - & + & ++ & ++ & + & - & - & - & - & + & ++ & ++ & + \\
\hline
\end{tabular}

Only two of four BSSs were weakly to moderately positive for Ber-Ep4, and staining in both was limited only to epithelial cells. All BMMs failed to decorate with this marker.

Although there was an overlap in the apoptotic markers p53, bcl-2, bax and cpp32 (caspase 3), there were quantitative differences. In general, p53 and bcl- 2 tended to be more strongly expressed in BSSs, while bax was more intense in BMMs.

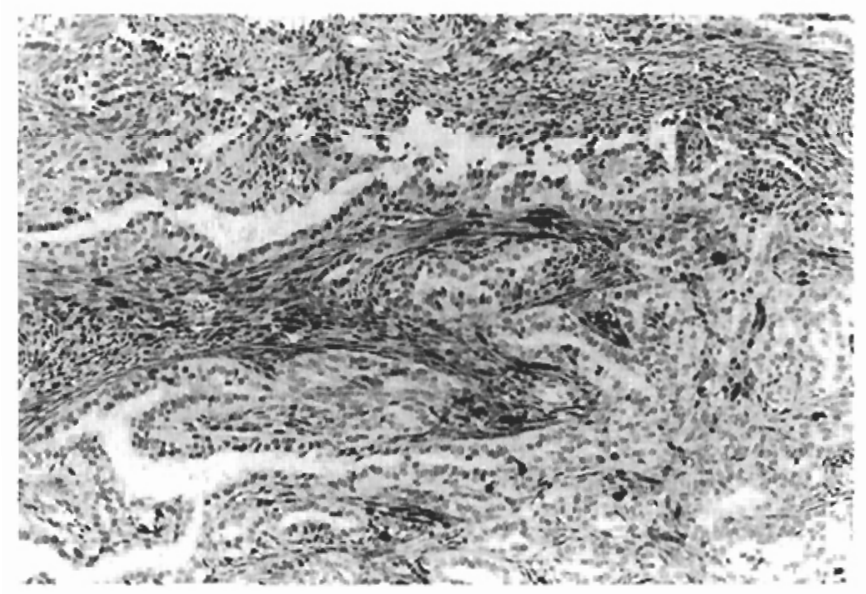

Fig. 3 Synovial sarcoma stained with calretinin. There is focal staining of the spindle cells in the centre of the illustration. The epithelial cells in this synovial sarcoma, in contrast to the epithelial cells in malignant mesothelioma, are negative for calretinin.

\section{DISCUSSION}

Synovial sarcoma of the pleural cavity is distinctly uncommon, with only nine cases documented in the literature. ${ }^{7-9}$ These are summarised in Table 5. Although Witken et al. have reported four cases in the mediastinum, "none appeared to be arising from a mesothelial surface" and, as a result, were not included in this review. ${ }^{12}$ Similarly, Zeren et al. have described 25 primary monophasic synovial

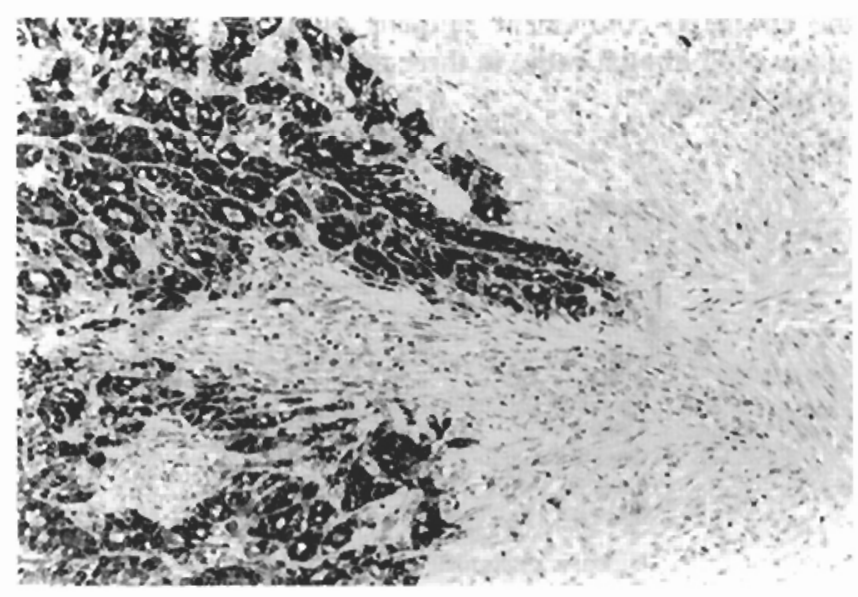

Fig. 4 Malignant mesothelioma stained with calretinin. Only the epithelial component is positive. Compare with Fig. 3. 
TABLE 5 Clinicopathological features of nine synovial sarcomas of the pleura

\begin{tabular}{|c|c|c|c|c|c|c|}
\hline Case & Age/sex & Initial symptoms & Radiological findings & $\begin{array}{l}\text { Tumour } \\
\text { size } \\
(\mathrm{cm})\end{array}$ & Treatment & Follow-up \\
\hline 1 & $17 \mathrm{~F}$ & $\begin{array}{l}\text { Dyspnea, chest } \\
\text { pain }\end{array}$ & $\begin{array}{l}\text { Left pleural effusion and } \\
\text { thickening, mediastinal } \\
\text { shift, consolidation of } \\
\text { lower } 2 / 3 \mathrm{~s} \text { of hemithorax }\end{array}$ & 21 & Surgery & DOD* within 12 months \\
\hline 2 & $17 \mathrm{~F}$ & Chest pain & $\begin{array}{l}\text { Left pleural thickening } \\
\text { with central mass }\end{array}$ & 9 & $\begin{array}{l}\text { Surgery, radiation, } \\
\text { chemotherapy }\end{array}$ & $\begin{array}{l}\text { Local recurrence, DOD } \\
\text { at } 18 \text { months }\end{array}$ \\
\hline 3 & $50 \mathrm{M}$ & Chest pain & Right pleural-based mass & 16 & $\begin{array}{l}\text { Surgery, radiation, } \\
\text { chemotherapy }\end{array}$ & DOD within 21 months \\
\hline 4 & $9 \mathrm{M}$ & $\begin{array}{l}\text { Dyspnea, chest } \\
\text { pain, fever }\end{array}$ & $\begin{array}{l}\text { Consolidation of left } \\
\text { upper lobe with probable } \\
\text { tumour }\end{array}$ & 5 & $\begin{array}{l}\text { Surgery, radiation, } \\
\text { chemotherapy }\end{array}$ & $\begin{array}{l}\text { AWD } \dagger \text { at } 8 \text { years with } \\
\text { regional and metastatic } \\
\text { disease }\end{array}$ \\
\hline 5 & $32 \mathrm{~F}$ & $\begin{array}{l}\text { Spontaneous } \\
\text { pneumothorax }\end{array}$ & $\begin{array}{l}\text { Right focally calcified } \\
\text { mass at periphery of } \\
\text { middle lobe }\end{array}$ & 9 & $\begin{array}{l}\text { Surgery, radiation, } \\
\text { phototherapy, } \\
\text { chemotherapy }\end{array}$ & $\begin{array}{l}\text { Local recurrence with } \\
\text { intra-abdominal spread; } \\
\text { DOD at } 30 \text { months }\end{array}$ \\
\hline 6 & $18 \mathrm{~F}$ & $\begin{array}{l}\text { Dyspnea, dry } \\
\text { cough, chest pain }\end{array}$ & $\begin{array}{l}\text { Density in lower } 2 / 3 \mathrm{~s} \text { of } \\
\text { right hemithorax }\end{array}$ & 17 & Surgery & $\begin{array}{l}\text { Local recurrence at } 5 \\
\text { months; AWD at } 16 \\
\text { months }\end{array}$ \\
\hline 7 & $42 \mathrm{M}$ & Dyspnea & $\begin{array}{l}\text { Right pleural effusion } \\
\text { and cystic-solid mass at } \\
\text { level of } 10 \text { th intercostal } \\
\text { space }\end{array}$ & 12 & $\begin{array}{l}\text { Surgery, } \\
\text { chemotherapy }\end{array}$ & AWD at 12 months \\
\hline 8 & $28 \mathrm{M}$ & $\begin{array}{l}\text { Chest pain, } \\
\text { dyspnea }\end{array}$ & $\begin{array}{l}\text { Right pleural effusion } \\
\text { with possible mass } \\
\text { involving pleural cavity, } \\
\text { lung and mediastinum }\end{array}$ & 12 & $\begin{array}{l}\text { Surgery, } \\
\text { chemotherapy }\end{array}$ & AWD at 9 months \\
\hline 9 & $42 \mathrm{M}$ & Chest pain & $\begin{array}{l}\text { Right pleural effusion } \\
\text { with possible pleural } \\
\text { mass }\end{array}$ & - & $\begin{array}{l}\text { Biopsy, } \\
\text { intrapleural and } \\
\text { systemic } \\
\text { chemotherapy }\end{array}$ & $\begin{array}{l}\text { Extensive local spread } \\
\text { through diaphragm into } \\
\text { left hypochondrium; } \\
\text { DOD at } 5 \text { months }\end{array}$ \\
\hline
\end{tabular}

${ }^{*}$ Dead of disease. $\nmid$ Alive with disease.

sarcomas of the lung, all of which were intrapulmonary and, as a consequence, did not involve mesothelioma in the differential diagnosis. ${ }^{13}$ They, too, were excluded from this study.

Because of the unusual location and histological similarity, synovial sarcoma is rarely included in the differential diagnosis of any pleural-based neoplasm and is almost invariably mistaken for a mesothelioma. The distinction is especially important because of differences in management and prognosis. ${ }^{14-21}$

There are a few clinical features, however, that may be useful in separating the two tumours. BSSs of the pleura tend to occur in individuals less than 45 years of age with no prior asbestos exposure, and present as discrete, localised masses, with or without effusions. Although pleural thickening may be seen, it tends to be uncommon. BMMs, in turn, tend to occur in individuals over the age of 45 years, often with a history of asbestos exposure. The tumours are generally diffuse, but sometimes localised. Pleural thickening with effusion is the rule.

Histologically, BSSs and BMMs are remarkably similar, and any differences are mainly quantitative and subtle (Figs. 1 and 2). In general, the spindled component of BSSs tends to be more compact and cellular with less collagen. Mast cells are prominent and glycogen is sparse. In contrast, the spindled element in BMMs is less compact and more collagenous. Mast cells are sparse and glycogen is abundant.
There are also differences in mucin content. In BSSs, the mucin is mucicarmine positive and resistant to hyaluronidase digestion. BMMs, in contrast, are generally mucicarmine negative and sensitive to hyaluronidase. One must, however, be cautious about placing too much diagnostic emphasis on mucin content. Some mucins are soluble in water-based fixatives and may leach out during tissue processing and give a false-negative reaction.

Although there are numerous studies that show the usefulness of immunohistochemistry in separating adenocarcinoma from mesothelioma, there are no immune markers that are unique for either mesothelioma or synovial sarcoma. ${ }^{22-26}$ of the antibodies used in our study, only calretinin, Ber-Ep4 and bcl-2 were of some limited discriminatory value (Table 4 ).

Calretinin is a $29-\mathrm{kDa}$ protein that belongs to the EF-hand family of calcium-binding proteins. ${ }^{27}$ It is normally expressed in neurons of the central and peripheral nervous system, as well as a variety of non-neural tissues, including steroid-producing cells of the testis and ovary, adipocytes, convoluted tubules of the kidney, eccrine glands, keratinising epithelial cells of the thymus and mesothelial cells. ${ }^{28}$ It is currently regarded as one of the most useful immune markers for separating mesothelioma from adenocarcinoma. Doglioni et al. observed nuclear and cytoplasmic calretinin reactivity in 44 of 44 mesotheliomas ( 36 epithelial, five biphasic and three sarcomatoid types).$^{28}$ Of the five BMMs in their report, staining was observed in both the epithelial $(3-4+)$ and spindle cells $(2+)$. They also studied three 
synovial sarcomas (monophasic versus biphasic not specified) and observed calretinin reactivity in only two $(1+)$. In our study, the epithelial component of four of four BMMs, was moderately to strongly positive for calretinin $(2-3+)$, while the spindle component was uniformly negative (Fig. 4). In contrast, the spindle component in four of four BSS s was weakly to moderately strong $(1-2+)$, while the epithelial component was weakly positive $(1+)$ in only one one of four (Table 4 and Fig. 3). These data, therefore, suggest that strong, diffuse calretinin reactivity in the epithelial component, with or without simultaneous staining of the spindle cells, is more indicative of a BMM than a BSS.

Ber-Ep4 is a monoclonal antibody that detects a cellsurface glycoprotein that is biochemically distinct from other commonly used epithelial-associated antigens, such as keratins, epithelial membrane antigen, Leu-Ml and carcinoembryonic antigen. ${ }^{23,24,29,30}$

Sheibani et al. studied 115 malignant mesotheliomas (71 epithelial, 29 sarcomatous and 15 biphasic) for the presence of Ber-Ep4, and only one biphasic tumour $(0.9 \%)$ showed diffuse membranous staining. ${ }^{23}$ Gaffey et al. studied 49 malignant mesotheliomas ( 32 epithelioid, and 17 biphasic), and observed that $10(20 \%)$ were positive for Ber-Ep4 (six epithelioid, four biphasic). ${ }^{24}$ The staining was membranous, restricted to the epithelial areas (not spindle component) and was focal, limited to less than $25 \%$ of the neoplastic cells. In our study, four of four BMMs were negative for Ber-Ep4 while two of four BSSs were focally positive in the epithelial component only. Of five pleural-based BSSs reported by Gaertner $e t$ al., five of five showed reactivity for Ber-Ep4 in the epithelial component and four of five showed reactivity in the spindle component. ${ }^{7}$ Based on these studies, a biphasic tumour of the pleura in which the epithelial component is negative or only focal positive for Ber-Ep4 would be more supportive of a BMM than a BSS.

Finally, Ordonez ${ }^{30}$ found that Ber-Ep4 reactivity of mesothelioma ranged from 0 to $88 \%$, and for adenocarcinoma from 32 to $100 \%$. Although he believed it was of some use in differentiating mesothelioma from pulmonary adenocarcinoma, he believed it was of limited value in differentiating mesothelioma from non-pulmonary adenocarcinoma or carcinomas of unknown primary. He went on to say that Ber-Ep4 should be used only when an additional marker is needed and not as part of the routine battery of immunohistochemical markers used to diagnose mesothelioma. We tend to agree with this assessment.

Although there was overlap in the expression of the apoptotic markers p53, bcl-2, bax and cpp32 (caspase 3), p53 and bcl-2 were more strongly expressed in BSSs, while bax was more intense in BMMs. Of these markers, the literature indicates that bcl-2 might be of value in distinguishing synovial sarcomas from mesotheliomas., ${ }^{9,31-35}$ Bcl-2, for instance, has been observed in the spindle component of $79-100 \%$ of synovial sarcomas, ${ }^{32,33,35}$ but only $0-10 \%$ of mesotheliomas. ${ }^{31-34}$ In our study, the spindle component was strongly positive $(3+)$ in four of four BSSs and weak to moderately positive $(1-2+)$ in four of four BMMs (Table 4). The epithelial component in two of four BSSs and four of four BMMs was also weakly to moderately positive $(1-2+)$. These data suggest that strong, diffuse bcl-2 staining of the spindle component is more indicative of a BSS than a BMM.
It is apparent that BSSs and BMMs share many similar immunohistochemical features and that any differences in expression in markers are mainly quantitative. It is, therefore, essential that the diagnosis of any biphasic malignant pleural-based tumour that includes BSS and BMM in the differential be made only after total consideration of the clinical, radiological, histochemical (mucin stains particularly) and immunohistochemical findings (Table 6). Reliance solely on immunomarkers is unreliable.

There are other sophisticated procedures, however, such as electron microscopy and cytogenetic-molecular studies, that may be helpful in distinguishing between these two tumours, but they require forethought of the differential diagnosis for proper tissue processing. Ultrastructurally, BMMs are characterised by long, tortuous microvilli and abundant glycogen, while in BSSs, the microvilli are shorter and glycogen is sparse to absent. ${ }^{3,10}$ Cytogenetic and molecular studies, in turn, have shown a unique translocation involving chromosomes $\mathrm{x}$ and 18 or its SYT-SSX fusion product in over $90 \%$ of synovial sarcomas. ${ }^{36-40}$

With the exception of bcl-2, the apoptotic markers p53, bax and cpp32 (caspase 3), did not allow one to distinguish between BSS and BMM. However, when viewed collectively, their distribution between the two tumours unexpectedly raised the question of whether they might be involved in their pathogenesis. It is now apparent that the process of carcinogenesis involves not only increased cell proliferation, but also decreased cell death (apoptosis) or increased cell survival. Apoptosis is a normal complex process of cell death designed to eliminate unwanted cells and is controlled by a group of genes and gene products, among which are p53, bcl-2, bax and caspases. ${ }^{41}$

$\mathrm{Bcl}-2$ is a normal, $26-\mathrm{kDa}$ protein that resides in the outer mitochondrial membrane, nuclear envelope, and parts of the endoplasmic reticulum. ${ }^{42,43}$ It is involved primarily in suppressing apoptosis and/or prolonging cell survival. Bax, in turn, is a $21-\mathrm{kDa}$ protein that promotes apoptosis or cell death by activating proteolytic enzymes (caspases) that dismantle the cell. p53, the "guardian of the genome", is a tumour suppresser gene located on the short arm of chromosome $17.4^{44}$ The gene encodes a nuclear phosphoprotein, whose half-life is very short, but regulates cell growth and division. If a mutagenic agent stresses a cell, p53 blocks the cell cycle to allow for DNA repair. If the reparative process fails, p53 induces the expression of pro-apoptotic genes, such as bax, to stimulate the apoptotic process. If, however, p53 is mutated, its half-life is prolonged, it accumulates at the nuclear level and DNA-damaged cells continue to propagate resulting in a tumoural mass.

In our study, we observed that p53 and bcl-2 tend to be more strongly expressed in BSSs than BMMs, while bax is less intense. The reversed pattern was observed in BMMs, that is, stronger reactivity for bax and weaker expression for p53 and bcl-2. Though the series is small and inconclusive, it does raise the issue and need for further studies to determine whether variances in apoptotic activity (weak in BSS, strong in BMM) might be responsible for the pathogenesis and differences in behavior of these neoplasms.

Address for correspondence: Dr Francesco Cappello, MD, Institute of Pathological Anatomy, University of Palermo, Via alla Falconara 120, 90136 Palermo, Italy. Email: francapp@hotmail.com 
TABLE 6 Clinical and pathological features that may be useful in separating pleural-based BSS from BMM

\begin{tabular}{|c|c|c|}
\hline Age & $<45 \mathrm{yr}$ & $>45 \mathrm{yr}$ \\
\hline $\operatorname{Sex}(\mathrm{M}: F)$ & $1: 1$ & $3: 1$ \\
\hline Asbestos exposure & No & Yes \\
\hline Effusion & Occasional & Very frequent \\
\hline Pleural thickening & Uncommon & Very frequent \\
\hline Tumour & Localised & Generally diffuse, infrequently localised \\
\hline $\begin{array}{l}\text { Histology } \\
\text { Spindle component } \\
\text { Haemangiopericytomatous-like pattern } \\
\text { Mast cells } \\
\text { Glycogen (PAS) }\end{array}$ & $\begin{array}{l}\text { Compact, cellular, less collagen } \\
\text { Frequent } \\
\text { Common } \\
\text { Sparse }\end{array}$ & $\begin{array}{l}\text { Less compact and cellular, more collagen } \\
\text { Rare } \\
\text { Rare } \\
\text { Abundant }\end{array}$ \\
\hline $\begin{array}{l}\text { Mucin histochemistry } \\
\text { Mucicarmine } \\
\text { Alcian blue-hyaluronidase } \\
\text { PAS diastase }\end{array}$ & $\begin{array}{l}+ \\
+ \\
+\end{array}$ & $\begin{array}{l}- \\
- \\
-\end{array}$ \\
\hline $\begin{array}{l}\text { Immunohistochemistry } \\
\text { Calretinin } \\
\text { Ber-Ep4 } \\
\text { Bcl-2 }\end{array}$ & $\begin{array}{l}\text { Epithelial: }+/- \\
\text { Spindle: }+/++ \\
\text { Epithelial: }+/- \\
\text { Spindle: }+/- \\
\text { Epithelial: }+/- \\
\text { Spindle: }++++\end{array}$ & $\begin{array}{l}\text { Epithelial: }+++ \\
\text { Spindle: }+/- \\
\text { Epithelial: }-(+)^{*} \\
\text { Spindle: }- \\
\text { Epithelial: }+ \\
\text { Spindle: }+/-\end{array}$ \\
\hline Electron microscopy & Short microvilli; sparse glycogen & Long, tortuous microvilli; abundant glycogen \\
\hline Cytogenetics $\mathrm{t}(\mathrm{x} ; 18)$ & $+($ over $90 \%)$ & - \\
\hline SST-SSX fusion & $+($ over $90 \%)$ & - \\
\hline Prognosis & $\begin{array}{l}\text { Pleura: } 7 / 9 \text { DOD at 5-30 months; } \\
\text { All sites: } 50-60 \% \text { 5-year survival }\end{array}$ & 12 months or less median survival \\
\hline
\end{tabular}

*Usually negative, rarely positive.

\section{References}

1. Cadman NL, Soule EH, Kelly PJ. Synovial sarcoma: An analysis of 134 tumors. Cancer 1965; 18: 613-27.

2. Tsuneyoshi M, Yokoyama E, Enjoji M. Synovial sarcoma: a clinicopathologic and ultrastructural study of 42 cases. Acta Pathol Jpn 1983; 33: 23-36.

3. Enzinger FM, Weiss SW, editors. Soft Tissue Tumors. 3rd ed. St Louis, MO: Mosby, 1995; 757-86.

4. Shmookler BM, Enzinger FM, Brannon RB. Orofacial synovial sarcoma. A clinicopathologic study of 11 new cases and review of the literature. Cancer 1982; 50: 269-76.

5. Holtz F, Magielski JE. Synovial sarcoma of the tongue base. The seventh reported case. Arch Otolaryngol 1985; 111: 271-2.

6. Fetsch JF, Meis JM. Synovial sarcoma of the abdominal wall. Cancer 1993; 72: 469-77.

7. Gaertner E, Zeren EH, Fleming MV, et al. Biphasic synovial sarcoma arising in the pleural cavity. A clinicopathologic study of five cases. Am J Surg Pathol 1996; 20: 36-45.

8. Jawahar DA, Vuletin JC, Gorecki P, et al. Primary biphasic synovial sarcoma of the pleura. Respir Med 1997; 91: 568-70.

9. Nicholson AG, Goldstraw P, Fisher C. Synovial sarcoma of the pleura and its differentiation from other primary pleural tumours: a clinicopathological and immunohistochemical review of three cases. Histopathology 1998; 33: 508-13.

10. Enzinger FM, Weiss SW, editors. Soft Tissue Tumors. 3rd ed. St Louis, MO: Mosby, 1995; 787-819.

11. Attanoos RL, Gibbs AR. Pathology of malignant mesothelioma. Histopathology 1997; 30: 403-18.

12. Witkin GB, Miettinen M, Rosai J. A biphasic tumor of the mediastinum with features of synovial sarcoma. A report of four cases. Am J Surg Pathol 1989; 13: 490-9.

13. Zeren H, Moran CA, Suster S, et al. Primary pulmonary sarcomas with features of monophasic synovial sarcoma. A clinicopathological, immunohistochemical, and ultrastructural study of 25 cases. Hum Pathol 1995; 26: 474-80.
14. Cagle LA, Mirra JM, Storm K, et al. Histologic features relating to prognosis in synovial sarcoma. Cancer 1987; 26: 1810-4.

15. Brodsky JT, Burt ME, Hajdu SI, et al. Tendosynovial sarcoma. Clinicopathologic features, treatment and prognosis. Cancer 1992; 70: 484-9.

16. Oda $\mathrm{Y}$, Hashimoto $\mathrm{H}$, Tsuneyoshi $\mathrm{M}$, et al. Survival in synovial sarcoma. A multivariate study of prognostic factors with special emphasis on the comparison between early death and long-term survival. Am J Surg Pathol 1993; 17: 35-44.

17. Beigh P, Meis-Kindblom JM, Gherlinzoni F, et al. Synovial sarcoma. Identification of low and high risk groups. Cancer 1999; 85: 2596-607.

18. Kampe CE, Rosen G, Eilber F, et al. Synovial sarcoma. A study of intensive chemotherapy in 14 patients with localized disease. Cancer 1993; 72: 2161--9.

19. Rosen G, Forscher C, Lowenbraun S, et al. Synovial sarcoma. Uniform response of metastases to high dose ifosfamide. Cancer 1994; 73: 2506-11.

20. Adams VI, Unni KK, Muhon JR, et al. Diffuse malignant mesothelioma of pleura. Diagnosis and survival in 92 cases. Cancer 1986; 58 : $1540-51$.

21. Vogelzang NJ. Malignant mesothelioma: diagnostic and management strategies for 1992. Semin Oncol 1992; 19: 64-71.

22. Ordonez NG. Value of cytokeratin 5/6 immunostaining in distinguishing epithelial mesothelioma of the pleura from lung adenocarcinoma. Am J Surg Pathol 1998; 22: 1215-21.

23. Sheibani K, Shin SS, Kezirian J, et al. Ber-EP4 antibody as a discriminant in the differential diagnosis of malignant mesothelioma versus adenocarcinoma. Am J Surg Pathol 1991; 15: 779-84.

24. Gaffey MJ, Mills SE, Swanson PE, et al. Immunoreactivity for BEREP4 in adenocarcinomas, adenomatoid tumors, and malignant mesotheliomas. Am J Surg Pathol 1992; 18: 593-9.

25. Vortmeyer AO, Preuss J, Padberg B-C, et al. Immunocytochemical differential diagnosis of diffuse pleural mesotheliomas: a clinicopathological study of 158 cases. Anticancer Res 1991;11:889-94. 
26. Ordonez NG. Role of immunohistochemistry in differentiating epithelial mesothelioma from adenocarcinoma. Review and update. Am J Clin Pathol 1991; 112: 75-89.

27. Heizmann $\mathrm{CW}$, Hunziker W. Intracellular calcium-binding proteins: more sites than insights. Trends Biochem Sci 1991; 16: 98-103.

28. Doglioni C, Dei Tos AP, Laurino L, et al. Calretinin: a novel immunocytochemical marker for mesothelioma. Am J Surg Pathol 1996; 20: 1037-46.

29. Latza U, Niedobitek G, Schwarting R, et al. Ber-EP4: new monoclonal antibody which distinguishes epithelia from mesothelia. J Clin Pathol 1990; 43: 213-9.

30. Ordonez NG. Value of the Ber-EP4 antibody in differentiating epithelial pleural mesothelioma from adenocarcinoma. The M.D. Anderson experience and a critical review of the literature. Am J Clin Pathol 1998; 109: 85-9.

31. Segers K, Ramael M, Singh SK, et al. Immunoreactivity for bcl-2 protein in malignant mesothelioma and non-neoplastic mesothelium. Virchows Arch 1994; 424: 631-4.

32. Hirakowa N, Naka T, Yamamoto I, et al. Over-expression of bcl-2 protein in synovial sarcoma: A comparative study of other soft tissue spindle cell sarcomas and an additional analysis by fluorescence in situ hybridization. Hum Pathol 1996; 27: 1060-5.

33. Nakanishi $\mathrm{H}$, Ohsawa $\mathrm{M}$, Naka $\mathrm{N}$, et al. Immunohistochemical detection of bcl-2 and p53 proteins and apoptosis in soft tissue sarcoma: their correlations with prognosis. Oncology 1997; 54: $238-44$.

34. Chilosi M, Facchetti F, Tos APD, et al. $\mathrm{Bcl}-2$ expression in pleural and extrapleural solitary fibrous tumors. J Pathol 1997; 181: 362-7.
35. Suster S, Fisher C, Moran CA. Expression of bcl-2 oncoprotein in benign and malignant spindle cell tumors of soft tissue, skin, serosal surfaces and gastrointestinal tract. Am J Surg Pathol 1998; 22: 863-72.

36. Dal Cin P, Rao U, Jani-Sait S, et al. Chromosomes in the diagnosis of soft tissue tumors. 1. Synovial sarcoma. Mod Pathol 1992; 5: 357-62.

37. Saboorian MH, Ashfag R, Vandersteenhoven JJ, et al. Cytogenetics as an adjunct in establishing a definitive diagnosis of synovial sarcoma by fine-needle aspiration. Cancer 1997; 81: 187-92.

38. Kawai A, Woodruff J, Healey JH, et al. SYT-SSX gene fusion as a determinant of morphology and prognosis in synovial sarcoma. New Engl J Med 1998; 338: 153-60.

39. Van de Rijn M, Barr FG, Xiong Q-B, et al. Poorly differentiated synovial sarcoma. An analysis of clinical, pathologic and molecular genetic features. Am J Surg Pathol 1999; 23: 106-12.

40. Van de Rijn M, Barr FG, Collins MH, et al. Absence of SYT-SSX fusion products in soft tissue tumors other than synovial sarcoma. Am J Clin Pathol 1999; 112: 43-9.

41. Contran RS, Kumar V, Collins T, editors. Robbins Pathologic Basis of Disease. 6th ed. Philadelphia: W B Saunders, 1999.

42. Krajewski S, Krajewska M, Shabaik A, et al. Immunohistochemical determination of in vivo distribution of bax, a dominant inhibitor of bcl-2. Am J Pathol 1994: 145: 1323-36.

43. Adams JM, Cory S. The bcl-2 protein family: arbiters of cell survival. Science 1998; 281: 1322-6.

44. Isobe M, Emmanauel BS, Givol D, et al. Localization of gene for human p53 tumor antigen to band 17 p13. Nature 1986; 320: 84-5. 